Article

\title{
First Case of Staphylococci Carrying Linezolid Resistance Genes from Laryngological Infections in Poland
}

\author{
Michał Michalik ${ }^{1}$, Maja Kosecka-Strojek ${ }^{2, *} \mathbb{B}$, Mariola Wolska ${ }^{2}$, Alfred Samet ${ }^{1}$, Adrianna Podbielska-Kubera ${ }^{1}$ \\ and Jacek Międzobrodzki ${ }^{2}$ \\ 1 MML Medical Centre, Bagno 2, 00-112 Warsaw, Poland; m.michalik@mml.com.pl (M.M.); \\ dr.alfredsamet@gmail.com (A.S.); adrianna.podbielska@mml.com.pl (A.P.-K.) \\ 2 Department of Microbiology, Faculty of Biochemistry, Biophysics and Biotechnology, Jagiellonian University, \\ Gronostajowa 7, 30-387 Kraków, Poland; mariola.wolska@doctoral.uj.edu.pl (M.W.); \\ jacek.miedzobrodzki@uj.edu.pl (J.M.) \\ * Correspondence: maja.kosecka-strojek@uj.edu.pl
}

check for

updates

Citation: Michalik, M.;

Kosecka-Strojek, M.; Wolska, M.;

Samet, A.; Podbielska-Kubera, A.;

Międzobrodzki, J. First Case of

Staphylococci Carrying Linezolid

Resistance Genes from

Laryngological Infections in Poland.

Pathogens 2021, 10, 335. https://

doi.org/10.3390/pathogens10030335

Academic Editor: Rachel McLoughlin

Received: 14 January 2021

Accepted: 10 March 2021

Published: 13 March 2021

Publisher's Note: MDPI stays neutral with regard to jurisdictional claims in published maps and institutional affiliations.

Copyright: (c) 2021 by the authors. Licensee MDPI, Basel, Switzerland. This article is an open access article distributed under the terms and conditions of the Creative Commons Attribution (CC BY) license (https:// creativecommons.org/licenses/by/ $4.0 /)$.

\begin{abstract}
Linezolid is currently used to treat infections caused by multidrug-resistant Gram-positive cocci. Both linezolid-resistant S. aureus (LRSA) and coagulase-negative staphylococci (CoNS) strains have been collected worldwide. Two isolates carrying linezolid resistance genes were recovered from laryngological patients and characterized by determining their antimicrobial resistance patterns and using molecular methods such as spa typing, MLST, SCCmec typing, detection of virulence genes and ica operon expression, and analysis of antimicrobial resistance determinants. Both isolates were multidrug resistant, including resistance to methicillin. The S. aureus strain was identified as ST398/t4474/SCCmec IVe, harboring adhesin, hemolysin genes, and the ica operon. The S. haemolyticus strain was identified as ST-42/mecA-positive and harbored hemolysin genes. Linezolid resistance in S. aureus strain was associated with the mutations in the ribosomal proteins L3 and L4, and in S. haemolyticus, resistance was associated with the presence of $c f r$ gene. Moreover, S. aureus strain harbored $\operatorname{optr} A$ and $\operatorname{poxt} A$ genes. We identified the first case of staphylococci carrying linezolid resistance genes from patients with chronic sinusitis in Poland. Since both S. aureus and CoNS are the most common etiological factors in laryngological infections, monitoring of such infections combined with surveillance and infection prevention programs is important to decrease the number of linezolid-resistant staphylococcal strains.
\end{abstract}

Keywords: antibiotic resistance; Staphylococcus aureus; Staphylococcus haemolyticus; chronic sinusitis; laryngological infections

\section{Introduction}

Linezolid, the first oxazolidinone antimicrobial approved in clinical practice, is currently used to treat infections caused by Gram-positive cocci, especially methicillin-resistant Staphylococcus aureus (MRSA) and vancomycin-resistant enterococci [1]. The first linezolidresistant $S$. aureus (LRSA) strain was detected in 2001 [2]. Since then, linezolid-resistant $S$. aureus strains have been collected worldwide, but most of them are related to (i) severe diseases such as cystic fibrosis [3,4], (ii) ICU patients [5,6] or (iii) chronic infections with long-term linezolid treatments [7]. Not only have S. aureus linezolid-resistant strains been reported, but increasing linezolid resistance in coagulase-negative staphylococci (CoNS) strains has also been observed. The first linezolid-resistant S. haemolyticus (LRSH) strain was reported by Rodríguez-Aranda et al. in 2009 [8]. Since then, a few strains (namely, 11) have been reported worldwide [9,10], but most of them were reported from China [11,12] and from India [13-15], with the last one in 2019 [16].

Linezolid reversibly binds and blocks the ribosomal peptidyl transferase center (PTC) and by this mechanism exerts bacteriostatic activity [17]. In staphylococcal clinical isolates, 
the mutation of the V domain of the 23S rRNA, namely, G2576U, is the most common modification of the ribosome at the PTC [2,9], but other mutations have also been identified [18]. Linezolid resistance has also been associated with mutations in the L3, L4, and L22 ribosomal proteins [18-20]. Moreover, the linezolid resistance, a transferable one, may be related to the cfr gene known since year 2000, and in staphylococci, firstly discovered in a bovine Staphylococcus sciuri strain and later reported also in other staphylococcal species [21]. The $c f r$ gene is not only responsible for resistance to oxazolidinones but also mediates cross-resistance to other antibiotics, such as phenicols, lincosamides, pleuromutilins, and streptogramin A [22]. Recently, the linezolid resistance was also associated with the novel transferable oxazolidinone resistance gene, namely optrA. First, it was identified, mainly in enterococci from humans and animals $[23,24]$ but recently, the optr $A$ gene was detected also in a single porcine $S$. sciuri strain $[25,26]$ and later confirmed in a few other $S$. sciuri strains [27]. In contrast to $c f r$ gene, optrA confers cross-resistance only to oxazolidinones, including tedizolid and phenicols. In 2018, Antonelli et al. described the novel gene, named poxtA, responsible also for transferable linezolid resistance in MRSA strains. The poxt $A$ gene encodes a protein of the ARE ABC-F family (lineage $F$ of the ABC superfamily proteins associated with antibiotic resistance), one of the ribosomal protection proteins [28]. The poxt $A$ gene is distantly related to optrA and able to cross-mediate susceptibility to phenicols, oxazolidinones, and tetracyclines. Moreover, it was also observed that poxt $A$ gene could act synergistically with other oxazolidinone resistance mechanisms to further increase the level of resistance to this group of antibiotics [28].

Linezolid resistance has also emerged in patients without linezolid exposure, which is probably due to cross-transmission between patients, horizontal transfer of linezolid resistance mediated by transferable genes among different CoNS species or co-selection by treatment with other antibiotics [15,22]. Moreover, linezolid-resistant strains are also resistant to other groups of antibiotics, especially linezolid resistant strains are often simultaneously resistant to $\beta$ lactams, so a proper characterization of broad resistance mechanisms is required [29].

In Poland, the only study related to linezolid resistant Staphylococcus strains recovered from ICU patients was published by our group in 2020 [6]. To date, there are no published reports related to linezolid-resistant strains detected in laryngological infections. Therefore, the study presented is the first in that field. Considering that staphylococci, including both S. aureus and CoNS, are the most frequent etiological factors in laryngological infections [30], their genetic and antimicrobial resistance profiles need to be further evaluated.

In the present study, two Staphylococcus isolates from laryngological infections were evaluated for their mechanisms of linezolid resistance and genetic profiles, and linked to patient characteristics.

\section{Results}

\subsection{Patient Characteristics}

Two patients hospitalized in the MML Center were evaluated. The first patient, a male of age 37, was diagnosed with chronic sinusitis. In 2013, the patient underwent nasal septum correction, correction of lower nasal turbinates by the Celon method, functional endoscopic surgery of the paranasal sinuses, removal of a foreign body from the left maxillary sinus, and correction of the soft palate by the Celon method. Then, in 2016, the patient was admitted to a clinic with purulent runny nose after dental treatment and diagnosed with chronic maxillary sinusitis. The patient was referred for functional endoscopic sinus surgery (FESS). The S. haemolyticus (WAW954 isolate) was cultured from the right sinus.

The second patient, a male aged 57, was admitted to the MML Center in the middle of 2016, diagnosed with chronic sinusitis, and qualified for surgery. The S. aureus (WAW1257 isolate) was cultured from right and left maxillary sinuses. During laryngological procedures, none of the patients were treated with linezolid. However, the first patient was 
treated with amoxycillin, clavic acid, and co-trimoxazole and the second patient with rifampicin and fusidic acid.

\subsection{Characteristics of Isolates and Identification at the Species Level}

A set of two isolates WAW1257 and WAW954 from the maxillary sinus collected from patients treated in the MML Medical Center were investigated. The preliminary identification with the $\operatorname{Vitek}^{\circledR} 2$ system identified the WAW1257 isolate as $S$. aureus and WAW954 as $S$. haemolyticus. Species identification was confirmed by four Sanger sequencing methods, namely, 16S rRNA, sodA, tuf, and rpoB genes.

\subsection{Genetic Profiling and Clonality Analysis}

Multilocus sequence typing (MLST) analysis revealed that S. aureus WAW1257 was ST398 and S. haemolyticus WAW954 was ST42. The S. aureus strain was assigned as spa type t4474. The SCCmec typing methods allowed for the identification of the SCCmec type IV subtype E for the WAW1257 strain and the presence of only the mecA gene in WAW954. The arginine catabolic mobile element (ACME) typing showed that WAW1257 contained ACME type II (arc+, opp3-) and WAW954 ACME type III (arc-,opp3+) (Table 1).

Table 1. Genetic profiles of S. aureus and S. haemolyticus strains isolated from laryngological patients.

\begin{tabular}{|c|c|c|c|c|c|}
\hline & MLST & spa Type & $\begin{array}{c}\text { SCCmec } \\
\text { Cassette } \\
\text { Type }\end{array}$ & ACME Type & $\begin{array}{c}\text { Virulence } \\
\text { and Biofilm } \\
\text { Formation } \\
\text { Genes }\end{array}$ \\
\hline $\begin{array}{c}\text { S. aureus } \\
\text { WAW1257 }\end{array}$ & $\begin{array}{c}\text { ST 398 } \\
\text { (arcC allel 3; } \\
\text { aroE allel 35; } \\
\text { glpF allel 19; } \\
\text { gmk allel 2; } \\
\text { pta allel 20; } \\
\text { tpi allel 26; } \\
\text { yqiL allel 39) }\end{array}$ & $\mathrm{t} 4474$ & IVE & II & $\begin{array}{c}\text { clfB, clfA, } \\
\text { fnbB, fib, hlg, } \\
\text { hla, hld, hlb, } \\
\text { icaABDC } \\
\text { operon }\end{array}$ \\
\hline $\begin{array}{c}\text { S. } \\
\text { haemolyticus } \\
\text { WAW954 }\end{array}$ & $\begin{array}{l}\text { ST42 } \\
\text { (arcC allel 1; } \\
\text { cfxE allel 1; } \\
\text { hemH allel 1; } \\
\text { leuB allel 1; } \\
\text { RiboseABC } \\
\text { allel 4; } \\
\text { SH1200 allel } \\
\text { 1; SH1431 } \\
\text { allel 5) }\end{array}$ & $\begin{array}{c}\text { not } \\
\text { applicable }\end{array}$ & mecA only & III & fib, hla, hlb \\
\hline
\end{tabular}

\subsection{Virulence and Biofilm Formation Genes}

The S. aureus (WAW1257) strain was positive for the $c l f B, c l f A, f n b B, f i b, h l g, h l a, h l d$, and $h l b$ genes, and $S$. haemolyticus WAW954 was positive for the fib, hla, and hlb genes. Additionally, the $S$. aureus strain harbored the icaABDC operon (Table 1).

\subsection{Antimicrobial Susceptibility and Resistance Determinants}

Based on the European Committee on antimicrobial susceptibility testing (EUCAST) breakpoints tables, the $S$. haemolyticus isolate was susceptible to only four antibiotics, tested in this study. Both isolates exhibited susceptibility to daptomycin and amikacin. Moreover, the S. aureus isolate was susceptible to fosfomycin, tigecycline, gentamicin, and S. haemolyticus to vancomycin and trimethoprim-sulfamethoxazole (Table 2). The linezolid resistance was tested with the E-test method and resulted in MIC $=3 \mu \mathrm{g} / \mathrm{mL}$ for $S$. aureus and MIC $=6 \mu \mathrm{g} / \mathrm{mL}$ for S. haemolyticus (Table 2). Therefore, S. aureus was assigned as linezolid susceptible and $S$. haemolyticus as resistant. 
Table 2. Antimicrobial susceptibility profiles and antibiotic resistance genes of S. aureus and S. haemolyticus strains.

\begin{tabular}{|c|c|c|c|c|c|c|}
\hline \multirow[b]{2}{*}{ Antibiotic } & \multicolumn{3}{|c|}{$\begin{array}{l}\text { Strain No. WAW1257 } \\
\text { (S. aureus) }\end{array}$} & \multicolumn{3}{|c|}{$\begin{array}{c}\text { Strain No. WAW954 } \\
\text { (S. haemolyticus) }\end{array}$} \\
\hline & $\begin{array}{c}\text { MIC } \\
(\mu \mathrm{g} / \mathrm{mL})\end{array}$ & $\begin{array}{l}\text { Interpretation } \\
\text { (S/R) }\end{array}$ & $\begin{array}{c}\text { Antibiotic } \\
\text { Restistance } \\
\text { Genes }\end{array}$ & $\begin{array}{c}\text { MIC } \\
(\mu \mathrm{g} / \mathrm{mL})\end{array}$ & $\begin{array}{l}\text { Interpretation } \\
\text { (S/R) }\end{array}$ & $\begin{array}{c}\text { Antibiotic } \\
\text { Restistance } \\
\text { Genes }\end{array}$ \\
\hline Linezolid & 3 & S & $\begin{array}{c}\text { optrA, poxtA, } \\
\text { T314C and } \\
\text { G362A } \\
\text { mutations in } \\
r p l C \text { (L3), C575T } \\
\text { mutation in } \\
\text { rplD (L4) }\end{array}$ & 6 & $\mathrm{R}$ & $c f r$ \\
\hline Cefoxitin & 48 & $\mathrm{R}$ & mec $A$ & 64 & $\mathrm{R}$ & mec $A$ \\
\hline Vancomycin & 3 & $\mathrm{R}$ & - & 4 & $S$ & - \\
\hline Teicoplanin & 3 & $\mathrm{R}$ & - & 6 & $\mathrm{R}$ & - \\
\hline Daptomycin & 1 & $S$ & - & 0.75 & $S$ & - \\
\hline Fosfomycin & 3 & S & - & 256 & $\mathrm{R}$ & - \\
\hline Ciprofloxacin & 32 & $\mathrm{R}$ & nor $A$ & 32 & $\mathrm{R}$ & - \\
\hline Tetracycline & 256 & $\mathrm{R}$ & - & 96 & $\mathrm{R}$ & - \\
\hline Tigecycline & 0.50 & $S$ & - & 1.5 & $\mathrm{R}$ & - \\
\hline Chloramphenicol & 48 & $\mathrm{R}$ & - & 256 & $\mathrm{R}$ & fexA \\
\hline Gentamicin & 0.75 & S & - & 24 & $\mathrm{R}$ & $\begin{array}{l}\operatorname{aac}\left(6^{\prime}\right)-I e- \\
\operatorname{aph}\left(2^{\prime \prime}\right)\end{array}$ \\
\hline Clindamycin & 256 & $\mathrm{R}$ & - & 256 & $\mathrm{R}$ & - \\
\hline Amikacin & 3 & $S$ & - & 6 & $S$ & - \\
\hline Erythromycin & 256 & $\mathrm{R}$ & - & 256 & $\mathrm{R}$ & - \\
\hline $\begin{array}{l}\text { Trimethoprim- } \\
\text { Sulfamethoxazole }\end{array}$ & 32 & $\mathrm{R}$ & - & 2 & $S$ & - \\
\hline Levofloxacin & 8 & $\mathrm{R}$ & nor $A$ & 32 & $\mathrm{R}$ & - \\
\hline Nitrofurantoin & 96 & $\mathrm{R}$ & - & 128 & $\mathrm{R}$ & - \\
\hline Benzylpenicillin & 24 & $\mathrm{R}$ & - & 256 & $\mathrm{R}$ & - \\
\hline
\end{tabular}

MICs were determined by the E-test method. R: Resistance; S: Susceptibility.

In our study, both $S$. aureus and S. haemolyticus strains exhibited intermediate levels of resistance to vancomycin, $\mathrm{MIC}=3 \mu \mathrm{g} / \mathrm{mL}$ for S. aureus and MIC $=4 \mu \mathrm{g} / \mathrm{mL}$ for S. haemolyticus. Therefore, both isolates were reported as vancomycin intermediate S. aureus (VISA) or vancomycin intermediate Staphylococcus sp. (VISS). Both S. aureus and S. haemolyticus strains were resistant to teicoplanin (Table 2). The S. haemolyticus isolate was also resistant to chloramphenicol and clindamycin, consistent with the presence of the $c f r$ and $f e x A$ genes. The occurrence of $c f r$ gene mediates in rendering the so-called PhLOPSA phenotype. S. haemolyticus was resistant to gentamicin, as confirmed by the presence of the aac $\left(6^{\prime}\right)-I e-$ aph (2") gene. The S. aureus strain was resistant to ciprofloxacin and levofloxacin, and had the nor A gene (Table 2). Additionally, the S. aureus strain demonstrated T314C and G362A changes in their deduced amino acid sequences of the L3 protein and C575T changes in their deduced amino acid sequences of the L4 protein. For S. aureus and S. haemolyticus strains, no changes occurred in the analyzed part of the 23S rRNA genes or in the L22 protein genes. For the S. haemolyticus strain, no changes occurred in the L3 or L4 protein genes. Moreover, the S. aureus strain harbored the optrA and poxtA genes (Table 2). Altogether, the strains were resistant to six various classes of antimicrobials, i.e., they were multidrug resistant.

\section{Discussion}

In the era of multidrug-resistant strains, linezolid is still an effective treatment agent for Gram-positive coccus infections [31]. Nevertheless, the increase in linezolid-resistant S. aureus, S. haemolyticus, and other CoNS is worrisome. Mostly, the number of linezolidresistant strains occurs after increased administration of an antibiotic but not always [3,4,29]. 
What is important, the linezolid resistance can emerge in CoNS after only a few days of treatment and in S. aureus strains, it usually occurs after a long time after the treatment [18].

In our study, to our knowledge, the patients were not exposed to linezolid prior to the isolation of the resistant strains. This acquisition of linezolid resistance may relate to the highly plastic nature of the CoNS genome, which is driven largely by insertion sequences and other mobile genetic elements [32]. Patients may have acquired the strains carrying the linezolid resistance genes from their environment, during their other hospital stay or could have also undergone the linezolid treatment due to infections other than sinusitis. Here, we describe the first cases of S. aureus and S. haemolyticus strains carrying linezolid resistance genes collected from patients with chronic sinusitis. In recent years, sinus infections have developed into chronic maxillary sinusitis over time in approximately $15 \%$ of patients [33]. The occurrence of multidrug-resistant strains in such patients is a next step in spreading antibiotic resistance, including the one for so-called last chance antibiotics such as vancomycin. In case of our strains, the divergent results of vancomycin resistance testing were most probably due to hetero-resistance [34]. Based on previous research, the precise cut-off values for both VISA and VISS phenotypes change with time and are different depending on the country [35]. Due to KORDL recommendations [36], we believe that our MIC values, which are slightly over breakpoint, can be considered as vancomycin-intermediate.

Unlike prior studies, where ST5 and ST188 were predominant among linezolidresistant strains (data for $S$. aureus) [3,37], in our study, the $S$. aureus strain belonged to ST398, one of the most frequent lineages of LA-MRSA in Europe [38,39]. It was observed that the occurrence of LA-MRSA in human is strongly associated with the increased contact with livestock [40]. Furthermore, it is known that ST398 often shows extensive resistance, which is selected by the widespread use of antibiotics in livestock farming [41,42]. In the present case, the patient affirmed that he was engaged in animal breeding activities (cattle and poultry) and lived in proximity to dogs and cats.

As reported previously, ST398 can be combined with SCCmec type IV [43,44], and such a situation also occurred in our study. Due to previous studies, it was reported that the SCCmec IV has smaller components and due to its increased mobility was found in different genetic backgrounds [45]. Moreover, SCCmec IV is mostly related to community-acquired MRSA (CA-MRSA) strains and is rarely found in health-care-associated MRSA strains (HA-MRSA) [46]. In recent years, it was also observed that SCCmec IV is present in several HA-MRSA clones, especially in Europe [47,48] but also worldwide [49,50]. Recent studies have reported that CA-MRSA strains are spreading in hospital settings and are replacing traditional HA-MRSA strains, especially in the United States of America [51,52].

To date, only a few reports on $\mathbf{t} 4474$ have been published. Data from one S. aureus strain belonging to 44474 isolated in Switzerland were submitted to a Ridom Spa Server database. Ho et al. published a study concerning MRSA from slaughtered pigs sampled from local markets in Hong Kong in 2012 [53], and Rodríguez-López et al. characterized MRSA from the Italian heavy swine production chain in 2020 [54]. Therefore, the worldwide distribution of this particular spa type is not exactly known. In our study, the S. aureus strain belonged to t4474, which is also consistent with the fact that the patient had contact with animals.

The arginine catabolic mobile element (ACME) was first described in methicillinresistant Staphylococcus aureus and is considered to enhance transmission, persistence, and survival. It was shown that ACME elements are especially prevalent in CoNS species [55]. Considering that not only the ACME is associated with the widespread S. aureus clones but also its high prevalence in S. epidermidis strains was noted [56], we believe that the detection of this element in S. aureus and CoNS strains from laryngological infections, where the strains must survive sometimes for a long time, is crucial for monitoring the transmission and better understanding such strains. ACME is integrated downstream of the SCCmec cassette and is flanked by repeat sequences, together with cassette chromosome recombinase ( $c c r)$ genes. It was proven, that $c c r$ genes catalyze the integration and excision 
of ACME from the staphylococcal chromosome [56], which is consistent with our study, that the ACME element coexists with SCCmec type IV [57-59]. In contrast to studies performed on S. aureus, the ACME in CoNS has not yet been thoroughly clarified [60]. Previously, ACME types were distinguished by characteristic presence profiles of the arc and opp3 operons but recently, two novel ACME types harboring the potassium transporter-encoding operon $k d p$ were described. In our study, the S. aureus strain possessed ACME type II, and the S. haemolyticus strain had ACME type III.

In our study, all the strains harbored virulence factors related to adhesion and hemolysis processes. In laryngological infections, not only are the adhesion-related factors important but also enzymes such as hemolysins can play a role in some of the effects of staphylococci on host organisms, with both involved in tissue destruction and as spreading factors facilitating invasion into nearby tissues [30]. Moreover, these factors may also be related to strains persistence in a host. In our study, the $S$. aureus strain also carried the $i c a A D B C$ locus, which is responsible for the production of polysaccharide intercellular adhesin (PIA), playing an important role in biofilm formation by bacteria [61]. In ICU patients with MRSA respiratory infection intubated for long periods, the systemic treatment with linezolid has a beneficial effect in limiting the MRSA burden [62,63]. Independent of that phenomenon, generally, the circulation of linezolid-resistant strains within a biofilm-associated operon generates a great risk for patients.

Although cfr-positive MRSA strains have occurred in many S. aureus lineages, in our study, the MRSA strain was cfr-negative and did not harbor mutations in the $\mathrm{V}$ region of $23 S$ rRNA. In our study, the S. aureus strain had two mutations in the L3 protein (T314C; G362A) and one in the L4 protein (C575T). The amino acid substitutions were detected based on a comparison with reference genomes of linezolid-sensitive $S$. aureus strains. The obtained sequences were compared to the reference $r p l C$ and $r p l D$ gene sequences of S. aureus NCTC8325, N315, and MW2. We believe that the unambiguous confirmation of these mutations should be determined by whole genome sequencing, which can be performed in the future. Moreover, the $S$. aureus strain harbored both optrA and poxt $A$ genes, responsible for transferable linezolid resistance. To our knowledge, this is the first detection of both optrA and poxtA genes and L3/L4 mutations in a single strain.

S. haemolyticus is a part of natural human skin microbiota and is, after S. epidermidis, the second most frequent species among clinical isolates of CoNS [64]. Nowadays, this species is recognized as an important nosocomial pathogen with a drift to develop multiple drug resistance, probably due to insertion sequences in its chromosome resulting in genomic rearrangements [65]. Indeed, S. haemolyticus was the first one among Gram-positive pathogens which acquired glycopeptide resistance and seems to show increased teicoplanin resistance in comparison to other CoNS [66]. In our study, the S. haemolyticus strain had only the mecA gene. Although, such structure of the SCCmec cassette was confirmed by two independent SCCmec typing methods, this is either a situation that the corresponding SCCmec element was non-typeable due to the alternative structure or modified primer binding sites or only the mecA gene is present. However, Miragaia et al. 2018 described that the CoNS species, including $S$. haemolyticus were characterized by high genetic diversity and recombination rate. Moreover, the ability to acquire and maintain exogenous genetic material or genetic mobile elements have been acquired earlier by these species than by $S$. aureus strains [67]. What is worrisome, the infection prevention controls, which are administered for MRSA are not used for CoNS and as a result, many multidrug resistant isolates, even those resistant to linezolid, stay undetected in health care settings. The detection of linezolid resistance in $S$. haemolyticus strains seems to be an emerging issue and requires stricter control to preserve linezolid for its clinical utility.

In our study, S. haemolyticus was PCR-positive for the $c f r$ and fexA genes. The fexA gene presence was consistent with chloramphenicol resistance and the $c f r$ gene detection conferred the S. haemolyticus PhLOPS a phenotype [22]. The cfr gene is located either in the chromosome or in plasmids or transposons which indicates a higher ability to transfer between strains $[68,69]$. The spread to susceptible populations or other pathogenic bacteria 
is facilitated. Moreover, the $c f r$-mediated resistance is related to an array of other antibiotics which limits therapeutic options. In Staphylococcus, the fexA gene is located in a small transposon Tn558 or in combination with the $c f r$ gene in transposition-deficient Tn558 variants [70]. Here, we link the $S$. haemolyticus resistance with the presence of $c f r$ gene, as no mutation in 23S rRNA nor L3/L4/L22 proteins was found. Such situation was observed for other linezolid resistant CoNS species [4,15,22].

To conclude, we identified the first cases of multidrug resistant $S$. aureus strain carrying linezolid resistance genes and linezolid-resistant $S$. haemolyticus strain from patients with chronic sinusitis in Poland. Since S. aureus and CoNS are the most common etiological factors of laryngological infections, monitoring linezolid resistance, together with the genetic characterization of such strains, is an emerging issue.

\section{Materials and Methods}

\subsection{Strain Collection}

The set of bacterial isolates used in this study included S. aureus (WAW1257) and S. haemolyticus (WAW954) clinical isolates carrying linezolid resistance genes recovered in 2016 from laryngological patients treated in MML Medical Center, Warsaw. Both isolates were recovered from maxillary sinuses. The preliminary identification of isolates was performed with a Vitek ${ }^{\circledR} 2$ Compact instrument (bioMérieux, La Balme Les Grottes, France).

\subsection{Susceptibility Testing}

Susceptibility testing was carried out according to the European Committee on Antimicrobial Susceptibility Testing (EUCAST; www.eucast.org/; accessed on 26 February 2021) recommendations. Minimum inhibitory concentration (MIC) values for linezolid, cefoxitin, vancomycin, teicoplanin, daptomycin, fosfomycin, ciprofloxacin, tetracycline, tigecycline, chloramphenicol, gentamicin, clindamycin, amikacin, erythromycin, trimethoprimsulfamethoxazole, levofloxacin, nitrofurantoin, and benzylpenicillin were determined using the E-test method.

\subsection{Total DNA Extraction}

For genomic DNA extraction, isolates were grown for $20 \mathrm{~h}$ at $37^{\circ} \mathrm{C}$ on blood agar plates. A full inoculation loop of $10 \mu \mathrm{L}$ of bacterial colonies was homogenized with a TissueLyser II (Qiagen, Germantown, MD, USA). The Qiagen DNeasy Blood and Tissue Kit (Qiagen, Germantown, MD, USA) was used for genomic DNA extraction. The subsequent steps were performed according to the manufacturer's instructions. Purified DNA was stored at $-20{ }^{\circ} \mathrm{C}$.

\subsection{Species Identification}

Both isolates were identified at the species level by sequencing the $16 \mathrm{~S}$ rRNA, sodA, $t u f$, and $r p o B$ genes, as previously described [71-74]. The PCR products were resolved by electrophoresis and purified using the Clean-Up Concentrator purification kit (A\&A Biotechnology, Gdynia, Poland). The concentration and purity were measured using a NanoDrop ND-1000. The PCR products were sequenced with the Sanger method at Genomed S.A. (Warsaw, Poland) with the same primers as those used for PCR.

\subsection{Molecular Analysis}

\subsubsection{Spa Typing}

Spa typing, based on the amplification of the variable $\mathrm{X}$ region of the protein A gene, was performed as described previously [75]. After sequencing, the spa type was assigned using the Ridom StaphType software version 2. 2. 1 (Ridom GmbH, Würzburg, Germany) and the Ridom SpaServer (https: / / spaserver.ridom.de/; accessed on 25 May 2020). 


\subsubsection{MLST Typing}

The clonality of isolates was studied using multilocus sequence typing (MLST) [76,77]. All PCR products were sequenced, and the S. aureus and S. haemolyticus MLST websites (https:/ / pubmlst.org/shaemolyticus/; accessed on 25 May 2021, https://pubmlst.org/ saureus/; accessed on 25 May 2020) were used to assign alleles and sequence types (STs) for allelic profiles [78].

\subsubsection{SCCmec Cassette Typing}

The SCCmec cassettes were typed with two independent methods, as described previously by Milheirico et al. [79] and Kondo et al. [80], with the USA300 strain as a positive control for the IV SCCmec cassette. The PCR products were resolved by electrophoresis, and the band patterns were analyzed.

\subsubsection{ACME Cassette Typing}

The presence of ACME cassettes in the $S$. aureus strain was detected by multiplex PCR targeting the arcA (AIPS27, AIPS28) and opp3A (AIPS45, AIPS46) genes using a previously described protocol [81] ( $\operatorname{arcA}$ AIPS27 5'-CTAACACTGAACCCCAATG-3'; AIPS28 5'-GAGCCAGAAGTACGCGAG-3'), (opp3A AIPS45-5'-GCAAATCTTAAATGGTCTGTTC$3^{\prime}$; AIPS46 5'-GAAGATTGGCAGCACAAAGTG-3'). Single PCR targeting the $\operatorname{arc} A$ and орр3B (opp3B-F, opp3B-R) genes was performed as previously described by $\mathrm{O}^{\prime}$ Connor et al. [82] for S. haemolyticus (opp3B opp3B-F 5'-GGATTCGCCCAAGTGATGACC-3'; opp3BR $5^{\prime}$-GACTGCTGGGTATGACGT-3'). The PCR products were resolved by electrophoresis, and the band patterns were analyzed.

\subsubsection{Detection of Virulence and ica Operon Genes}

The PCRs for the detection of virulence determinants such as adhesins, hemolysins, and biofilm formation genes were performed as described in Table 3. The PCR products were resolved by electrophoresis, and the band patterns were analyzed.

\subsubsection{Detection and Analysis of Antimicrobial Resistance Determinants}

Detection of the $c f r$, fexA, nor A, aac(6)-Ie-aph (2") genes was performed as previously described $[5,6,70,83-86]$. Additionally, the presence of optr $A$ and poxt $A$ genes was checked $[23,87]$. All the PCR products were resolved by electrophoresis, and the band patterns were analyzed.

The genes encoding the PTC-associated ribosomal proteins L3 (rplC), L4 (rplD), L22 $(r p l V)$, and 23S rRNA were amplified with the primers and PCR conditions described in Table 4. The PCR products were cleaned and concentrated with a Clean-Up Concentrator purification kit (A\&A Biotechnology, Gdynia, Poland) and sequenced (Genomed S.A., Warsaw, Poland) with primers for individual ribosomal protein genes. The obtained sequences were compared to the reference $r p l C, r p l D, r p l V$, and $23 \mathrm{~S}$ rRNA gene sequences for S. haemolyticus JCSC1435 (GenBank accession number: NC_007168.1) and S. aureus NCTC8325, N315 and MW2 (GenBank accession numbers: NZ_LS483365.1, NC_002745.2, and NC_003923.1). 
Table 3. The nucleotide sequences of primers used for the detection of the virulence genes.

\begin{tabular}{|c|c|c|c|c|}
\hline & Gene & Sequence $\left(5^{\prime}-3^{\prime}\right)$ & $\begin{array}{l}\text { Product Size } \\
\text { (bp) }\end{array}$ & References \\
\hline \multirow{11}{*}{ Adhesin genes } & \multirow{2}{*}{ clfB (S. aureus) } & ACATCAGTAATAGTAGGGGGCAAC & \multirow{2}{*}{205} & \multirow{9}{*}{ [88] } \\
\hline & & TTCGCACTGTTTGTGTTTGCAC & & \\
\hline & \multirow{2}{*}{ clfA (S. aureus) } & ATTGGCGTGGCTTCAGTGCT & \multirow{2}{*}{292} & \\
\hline & & CGTTTCTTCCGTAGTTGCATTTG & & \\
\hline & fnbB (S. aureus) & GTAACAGCTAATGGTCGAATTGATACT & 524 & \\
\hline & \multirow{2}{*}{ fnbA (S. aureus) } & GTGAAGTTTTAGAAGGTGGAAAGATTAG & \multirow{2}{*}{643} & \\
\hline & & GCTCTTGTAAGACCATTTTTCTTCAC & & \\
\hline & \multirow{2}{*}{ fib (S. aureus) } & CTACAACTACAATTGCCGTCAACAG & \multirow{2}{*}{404} & \\
\hline & & GCTCTTGTAAGACCATTTTCTTCAC & & \\
\hline & \multirow{2}{*}{ fib (S. haemolyticus) } & TTATTTGACTTTCATACTTTGTA & \multirow{2}{*}{1698} & \multirow{2}{*}{ This study } \\
\hline & & ATGGCATATGATGGCTTATTCA & & \\
\hline \multirow{11}{*}{ Hemolysin genes } & hla (S. aureus) & CTTTCCAGCCTACTTTTTTATCAGT & 209 & \multirow{5}{*}{ [89] } \\
\hline & \multirow{2}{*}{ hlg (S. aureus) } & GTCAYAGAGTCCATAATGCATTTAA & \multirow{2}{*}{535} & \\
\hline & & CACCAAATGTATAGCCTAAAGTG & & \\
\hline & \multirow{2}{*}{ hld (S. aureus) } & AAGAATTTTTATCTTAATTAAGGAAGGAGTG & \multirow{2}{*}{111} & \\
\hline & & TTAGTGAATTTGTTCACTGTGTCGA & & \\
\hline & \multirow{2}{*}{ hlb (S. aureus) } & GCAATATAAACGCGCTGATTTAATCG & \multirow{2}{*}{518} & \multirow{2}{*}{ [90] } \\
\hline & & GAGTGCCTTTATTGACATTAAGGTCG & & \\
\hline & \multirow{2}{*}{ hla (S. haemolyticus) } & TGGGCCATAAACTTCAATCGC & \multirow{2}{*}{72} & \multirow{2}{*}{ [91] } \\
\hline & & ACGCCACCTACATGCAGATTT & & \\
\hline & \multirow{2}{*}{ hlb (S. haemolyticus) } & ATGTCTAACTCAACTAAGAATGC & \multirow{2}{*}{684} & \multirow{2}{*}{ This study } \\
\hline & & CTAAATAAAATAAAGTATTGCTA & & \\
\hline
\end{tabular}


Table 3. Cont.

\begin{tabular}{|c|c|c|c|c|}
\hline & Gene & Sequence $\left(5^{\prime}-3^{\prime}\right)$ & $\begin{array}{l}\text { Product Size } \\
\text { (bp) }\end{array}$ & References \\
\hline \multirow{7}{*}{$\begin{array}{c}i c a \text { operon } \\
\text { (S. aureus and S. haemolyticus) }\end{array}$} & \multirow{2}{*}{$i c a A$} & ACACTTGCTGGCGCAGTCAA & \multirow{2}{*}{188} & \multirow{2}{*}{ [92] } \\
\hline & & TCTGGAACCAACATCCAACA & & \\
\hline & \multirow{2}{*}{$i c a B$} & AGAATCGTGAAGTATAGAAAATT & \multirow{2}{*}{900} & \multirow{3}{*}{ [93] } \\
\hline & & TCTAATCTTTTTCATGGAATCCGT & & \\
\hline & $i c a C$ & ATGGGACGGATTCCATGAAAAAGA & 1100 & \\
\hline & \multirow{2}{*}{$i c a D$} & ATGGTCAAGCCCAGACAGAG & \multirow{2}{*}{198} & \multirow{2}{*}{ [92] } \\
\hline & & AGTATTTTCAATGTTTAAAGCAA & & \\
\hline
\end{tabular}


Table 4. Primer sequences and PCR conditions used to the amplification and sequencing of $23 \mathrm{~S}$ rRNA, $r p l C, r p l D, r p l V$ genes.

\begin{tabular}{|c|c|c|c|c|c|}
\hline Target Genes & & Sequence $\left(5^{\prime}-3^{\prime}\right)$ & PCR Conditions & Cycles (Steps 2-4) & Reference \\
\hline \multirow{3}{*}{$\begin{array}{l}r p l C(\mathrm{~L} 3) \\
822-\mathrm{bp}\end{array}$} & $\begin{array}{c}\text { rplC-F } \\
\text { (S. aureus) }\end{array}$ & AACCTGATTTAGTTCCGTCTA & $\begin{array}{l}94^{\circ} \mathrm{C} \text { for } 2 \mathrm{~min} \\
94^{\circ} \mathrm{C} \text { for } 1 \mathrm{~min}\end{array}$ & \multirow{3}{*}{33} & \multirow[t]{2}{*}{ [94] } \\
\hline & rplC-R & GTTGACGCTTTAATGGGCTTA & \multirow{2}{*}{$\begin{array}{l}50{ }^{\circ} \mathrm{C} \text { for } 1 \mathrm{~min} \\
72{ }^{\circ} \mathrm{C} \text { for } 1 \mathrm{~min} \\
72{ }^{\circ} \mathrm{C} \text { for } 5 \mathrm{~min}\end{array}$} & & \\
\hline & $\begin{array}{c}\mathrm{rplC}-\mathrm{F} \\
\text { (S. haemolyticus) }\end{array}$ & ACCCTGATTTAGTTCCGTCTA & & & [95] \\
\hline \multirow{3}{*}{$\begin{array}{l}r p l D(L 4) \\
1099-b p\end{array}$} & rplD-F & TCGCTTACCTCCTTAATG & $95^{\circ} \mathrm{C}$ for $5 \mathrm{~min}$ & \multirow{3}{*}{30} & \multirow{3}{*}[94]{} \\
\hline & & & $95^{\circ} \mathrm{C}$ for $30 \mathrm{~s}$ & & \\
\hline & rplD-R & GGTGGAAACACTGTAACTG & $72{ }^{\circ} \mathrm{C}$ for $10 \mathrm{~min}$ & & \\
\hline \multirow{4}{*}{$\begin{array}{l}r p l V(\mathrm{~L} 22) \\
520-\mathrm{bp}\end{array}$} & rplV-F & TTTCAGCATACCATTTTGCTTCC & $94^{\circ} \mathrm{C}$ for $2 \mathrm{~min}$ & \multirow{4}{*}{30} & \multirow{7}{*}{ [6] } \\
\hline & & & $94^{\circ} \mathrm{C}$ for $10 \mathrm{~s}$ & & \\
\hline & & & $50^{\circ} \mathrm{C}$ for $30 \mathrm{~s}$ & & \\
\hline & rplV-R & TAAAGGACATGCAGCAGACG & $\begin{array}{c}72{ }^{\circ} \mathrm{C} \text { for } 30 \mathrm{~s} \\
72^{\circ} \mathrm{C} \text { for } 5 \mathrm{~min}\end{array}$ & & \\
\hline \multirow{3}{*}{$\begin{array}{l}23 \mathrm{~S} \text { rRNA } \\
846-\mathrm{bp}\end{array}$} & 23S-F & CGGCGGCCGTAACTATAACG & $95^{\circ} \mathrm{C}$ for $5 \mathrm{~min}$ & \multirow{3}{*}{30} & \\
\hline & & & $72{ }^{\circ} \mathrm{C}$ for $30 \mathrm{~s}$ & & \\
\hline & 23S-R & CAGCACTTATCCCGTCCATAC & $72{ }^{\circ} \mathrm{C}$ for $10 \mathrm{~min}$ & & \\
\hline
\end{tabular}




\subsection{Nucleotide Sequence Accession Numbers}

The eight sequences for one Staphylococcus haemolyticus and one Staphylococcus aureus were annotated using the NCBI BankIt tool and deposited in the GenBank database (https: / / www.ncbi.nlm.nih.gov/genbank/) under the following accession numbers: For the 16S rRNA gene, MW267294 and MW267295; for the sodA gene, MW272559 and MW272560; for the tuf gene, MW272562 and MW272563; and for the rpoB gene, MW272556 and MW272557.

Author Contributions: Conceptualization, M.M., M.K.-S., and J.M.; methodology, M.K.-S.; validation, M.M. and M.K.-S.; investigation, M.M., M.K.-S., and M.W.; resources, M.M., A.S., and A.P.-K.; data curation, M.K.-S.; writing—original draft preparation, M.K.-S.; writing—review and editing, M.M., M.K.-S., M.W., A.P.-K., A.S., and J.M.; visualization, M.M. and M.W.; supervision, M.K.-S. All authors have read and agreed to the published version of the manuscript.

Funding: Not applicable.

Institutional Review Board Statement: Not applicable.

Informed Consent Statement: Written informed consent has been obtained from the patient(s) to publish this paper.

Data Availability Statement: The datasets generated for this study can be found in Genbank, MW267294-MW267295; MW272559-MW272560; MW272562-MW272563; MW272556-MW272557.

Acknowledgments: The publication made use of the PubMLST website (https://pubmlst.org/) developed by Keith Jolley (Jolley et al. Welcome Open Res 2018, 3:124) and sited at the University of Oxford. The development of that website was funded by the Welcome Trust.

Conflicts of Interest: The authors declare no conflict of interest.

Ethics Approval: For this type of study, a formal consent is not required.

\section{References}

1. Sorlozano, A.; Gutierrez, J.; Martinez, T.; Yuste, M.E.; Perez-Lopez, J.A.; Vindel, A.; Guillén, J.; Boquete, T.; Martınez, T. Detection of new mutations conferring resistance to linezolid in glycopeptide-intermediate susceptibility Staphylococcus hominis subspecies hominis circulating in an intensive care unit. Eur. J. Clin. Microbiol. Infect. Dis. 2009, 29, 73-80. [CrossRef]

2. Tsiodras, S.; Gold, H.S.; Sakoulas, G.; Eliopoulos, G.M.; Wennersten, C.; Venkataraman, L.; Moellering, R.C.; Ferraro, M.J. Linezolid resistance in a clinical isolate of Staphylococcus aureus. Lancet 2001, 358, 207-208. [CrossRef]

3. Endimiani, A.; Blackford, M.; Dasenbrook, E.C.; Reed, M.D.; Bajaksouszian, S.; Hujer, A.M.; Rudin, S.D.; Hujer, K.M.; Perreten, V.; Rice, L.B.; et al. Emergence of Linezolid-Resistant Staphylococcus aureus after Prolonged Treatment of Cystic Fibrosis Patients in Cleveland, Ohio. Antimicrob. Agents Chemother. 2011, 55, 1684-1692. [CrossRef] [PubMed]

4. de Dios Caballero, J.; Pastor, M.D.; Vindel, A.; Máiz, L.; Yagüe, G.; Salvador, C.; Cobo, M.; Morosini, M.-I.; Del Campo, R.; Cantón, R.; et al. Emergence of cfr-Mediated Linezolid Resistance in a Methicillin-Resistant Staphylococcus aureus Epidemic Clone Isolated from Patients with Cystic Fibrosis. Antimicrob. Agents Chemother. 2015, 60, 1878-1882. [CrossRef]

5. Morales, G.; Picazo, J.J.; Baos, E.; Candel, F.J.; Arribi, A.; Peláez, B.; Andrade, R.; De La Torre, M.; Fereres, J.; Sánchez-García, M. Resistance to Linezolid Is Mediated by the cfr Gene in the First Report of an Outbreak of Linezolid-Resistant Staphylococcus aureus. Clin. Infect. Dis. 2010, 50, 821-825. [CrossRef] [PubMed]

6. Kosecka-Strojek, M.; Sadowy, E.; Gawryszewska, I.; Klepacka, J.; Tomasik, T.; Michalik, M.; Hryniewicz, W.; Miedzobrodzki, J. Emergence of linezolid-resistant Staphylococcus epidermidis in the tertiary children's hospital in Cracow, Poland. Eur. J. Clin. Microbiol. Infect. Dis. 2020, 39, 1727-1737. [CrossRef] [PubMed]

7. Yoshida, K.; Shoji, H.; Niki, Y.; Hanaki, H.; Yanagisawa, C.; Ikeda-Dantsuji, Y.; Fukuchi, K.; Adachi, M. Linezolid-resistant methicillin-resistant Staphylococcus aureus isolated after long-term, repeated use of linezolid. J. Infect. Chemother. 2009, 15, 417-419. [CrossRef]

8. Rodríguez-Aranda, A.; Daskalaki, M.; Villar, J.; Sanz, F.; Otero, J.R.; Chaves, F. Nosocomial spread of linezolid-resistant Staphylococcus haemolyticus infections in an intensive care unit. Diagn. Microbiol. Infect. Dis. 2009, 63, 398-402. [CrossRef]

9. Mazzariol, A.; Cascio, G.L.; Kocsis, E.; Maccacaro, L.; Fontana, R.; Cornaglia, G. Outbreak of linezolid-resistant Staphylococcus haemolyticus in an Italian intensive care unit. Eur. J. Clin. Microbiol. Infect. Dis. 2011, 31, 523-527. [CrossRef] [PubMed]

10. Tewhey, R.; Gu, B.; Kelesidis, T.; Charlton, C.; Bobenchik, A.; Hindler, J.; Schork, N.J.; Humphries, R.M. Mechanisms of Linezolid Resistance among Coagulase-Negative Staphylococci Determined by Whole-Genome Sequencing. mBio 2014, 5, e00894-14. [CrossRef]

11. Cui, L.; Wang, Y.; Li, Y.; He, T.; Schwarz, S.; Ding, Y.; Shen, J.; Lv, Y. cfr-Mediated Linezolid-Resistance among Methicillin-Resistant Coagulase-Negative Staphylococci from Infections of Humans. PLoS ONE 2013, 8, e57096. [CrossRef] 
12. Jian, J.; Chen, L.; Xie, Z.; Zhang, M. Dissemination of cfr-mediated linezolid resistance among Staphylococcus species isolated from a teaching hospital in Beijing, China. J. Int. Med. Res. 2018, 46, 3884-3889. [CrossRef]

13. Rajan, V.; Kumar, V.G.S.; Gopal, S. A cfr-positive clinical staphylococcal isolate from India with multiple mechanisms of linezolidresistance. Indian J. Med. Res. 2014, 139, 463-467. [PubMed]

14. Dhawan, B.; Kumari, S.; Rawre, J.; Trikha, A.; Sreenivas, V.; Sood, S.; Kapil, A. Linezolid-resistant Staphylococcus haemolyticus: Emergence of G2447U \& C2534U mutations at the domain V of 23S ribosomal RNA gene in a tertiary care hospital in India. Indian J. Med. Res. 2019, 149, 795-798. [CrossRef]

15. Mittal, G.; Bhandari, V.; Gaind, R.; Rani, V.; Chopra, S.; Dawar, R.; Sardana, R.; Verma, P.K. Linezolid resistant coagulase negative staphylococci (LRCoNS) with novel mutations causing blood stream infections (BSI) in India. BMC Infect. Dis. 2019, 19, 717. [CrossRef] [PubMed]

16. Vijayan, P.; Srinivas, D.; Siddaiah, N.; Bahubali, V.K.H. Device-Associated Meningitis by Linezolid-Resistant Staphylococcus haemolyticus in a Vancomycin- Hypersensitive Patient. J. Neurosci. Rural. Pr. 2019, 10, 718-720. [CrossRef]

17. Long, K.S.; Vester, B. Resistance to Linezolid Caused by Modifications at Its Binding Site on the Ribosome. Antimicrob. Agents Chemother. 2011, 56, 603-612. [CrossRef]

18. Gu, B.; Kelesidis, T.; Tsiodras, S.; Hindler, J.; Humphries, R.M. The emerging problem of linezolid-resistant Staphylococcus. J. Antimicrob. Chemother. 2013, 68, 4-11. [CrossRef] [PubMed]

19. Mendes, R.E.; Deshpande, L.M.; Jones, R.N. Linezolid update: Stable in vitro activity following more than a decade of clinical use and summary of associated resistance mechanisms. Drug Resist. Updat. 2014, 17, 1-12. [CrossRef]

20. Takaya, A.; Kimura, A.; Sato, Y.; Ishiwada, N.; Watanabe, M.; Matsui, M.; Shibayama, K.; Yamamoto, T. Molecular characterization of linezolid-resistant CoNS isolates in Japan. J. Antimicrob. Chemother. 2015, 70, 658-663. [CrossRef] [PubMed]

21. Fessler, A.T.; Calvo, N.; Gutiérrez, N.; Bellido, J.L.M.; Fajardo, M.; Garduño, E.; Monecke, S.; Ehricht, R.; Kadlec, K.; Schwarz, S.; et al. cfr-mediated linezolid resistance in methicillin-resistant Staphylococcus aureus and Staphylococcus haemolyticus associated with clinical infections in humans: Two case reports. J. Antimicrob. Chemother. 2014, 69, 268-285. [CrossRef]

22. Long, K.S.; Poehlsgaard, J.; Kehrenberg, C.; Schwarz, S.; Vester, B. The cfr rRNA methyltransferase confers resistance to phenicols, lincosamides, oxazolidinones, pleuromutilins, and streptogramin a antibiotics. Antimicrob Agents Chemother 2006, 50, $2500-2505$. [CrossRef] [PubMed]

23. Gawryszewska, I.; ZZabicka, D.; Hryniewicz, W.; Sadowy, E. Linezolid-resistant enterococci in Polish hospitals: Species, clonality and determinants of linezolid resistance. Eur. J. Clin. Microbiol. Infect. Dis. 2017, 36, 1279-1286. [CrossRef] [PubMed]

24. He, T.; Shen, Y.; Schwarz, S.; Cai, J.; Lv, Y.; Li, J.; Feßler, A.T.; Zhang, R.; Wu, C.; Shen, J.; et al. Genetic environment of the transferable oxazolidinone/phenicol resistance gene optrA in Enterococcus faecalis isolates of human and animal origin. J. Antimicrob. Chemother. 2016, 71, 1466-1473. [CrossRef] [PubMed]

25. Fan, R.; Li, D.; Wang, Y.; He, T.; Feßler, A.T.; Schwarz, S.; Wu, C. Presence of the optrA gene in methicillin-resistant Staphylococcus sciuri of porcine origin. Antimicrob Agents Chemother 2016, 60, 7200-7205. [PubMed]

26. Li, D.; Wang, Y.; Schwarz, S.; Cai, J.; Fan, R.; Li, J.; Feßler, A.T.; Zhang, R.; Wu, C.; Shen, J. Co-location of the oxazolidinone resistance genes optrA and cfr on a multi-resistance plasmid from Staphylococcus sciuri. J Antimicrob. Chemother. 2016, 71, 1474-1478. [CrossRef]

27. Wu, Y.; Fan, R.; Wang, Y.; Lei, L.; Feßler, A.T.; Wang, Z.; Wu, C.; Schwarz, S.; Wang, Y. Analysis of combined resistance to oxazolidinones and phenicols among bacteria from dogs fed with raw meat/vegetables and the respective food items. Sci. Rep. 2019, 9, 15500. [CrossRef] [PubMed]

28. Antonelli, A.; D'Andrea, M.M.; Brenciani, A.; Galeotti, C.L.; Morroni, G.; Pollini, S.; Varaldo, P.E.; Rossolini, G.M. Characterization of poxtA, a novel phenicol-oxazolidinone-tetracycline resistance gene from an MRSA of clinical origin. J. Antimicrob. Chemother. 2018, 73, 1763-1769. [CrossRef]

29. Rouard, C.; Garnier, F.; Leraut, J.; Lepainteur, M.; Rahajamananav, L.; Languepin, J.; Ploy, M.-C.; Bourgeois-Nicolaos, N.; Doucet-Populaire, F. Emergence and Within-Host Genetic Evolution of Methicillin-Resistant Staphylococcus aureus Resistant to Linezolid in a Cystic Fibrosis Patient. Antimicrob. Agents Chemother. 2018, 62, e00720-18. [CrossRef] [PubMed]

30. Michalik, M.; Samet, A.; Podbielska-Kubera, A.; Savini, V.; Międzobrodzki, J.; Kosecka-Strojek, M. Coagulase-negative staphylococci (CoNS) as a significant etiological factor of laryngological infections: A review. Ann. Clin. Microbiol. Antimicrob. 2020, 19, 26. [CrossRef] [PubMed]

31. Perez, F.; Salata, R.A.; Bonomo, R.A. Current and novel antibiotics against resistant Gram-positive bacteria. Infect. Drug Resist. 2008, 1, 27-44. [CrossRef] [PubMed]

32. Schoenfelder, S.M.; Lange, C.; Eckart, M.; Hennig, S.; Kozytska, S.; Ziebuhr, W. Success through diversity-How Staphylococcus epidermidis establishes as a nosocomial pathogen. Int. J. Med. Microbiol. 2010, 300, 380-386. [CrossRef] [PubMed]

33. Battisti, A.S.; Modi, P.; Pangia, J. Sinusitis. In StatPearls [Internet]. Treasure Island (FL); StatPearls Publishing: Treasure Island, FL, USA, 2020.

34. Deresinski, S. Vancomycin Heteroresistance and Methicillin-Resistant Staphylococcus aureus. J. Infect. Dis. 2009, 199, 605-609. [CrossRef] [PubMed]

35. Weinstein, R.A.; Fridkin, S.K. Vancomycin-Intermediate and -Resistant Staphylococcus aureus: What the Infectious Disease Specialist Needs to Know. Clin. Infect. Dis. 2001, 32, 108-115. [CrossRef] 
36. European Committee on Antimicrobial Susceptibility Testing. Breakpoints Tables for Interpretation of MICs and Zones Diameters. Version 10.0. 2020. Available online: http:/ / www.eucast.org (accessed on 26 February 2021).

37. Li, S.; Zhao, L.; Zheng, B.; Shen, P.; Ji, J.; Lv, J.; Li, L.; Xiao, Y. Identification and characterization of cfr-positive Staphylococcus aureus isolates from community-onset infectious patients in a county hospital in China. J. Med Microbiol. 2015, 64, 910-915. [CrossRef]

38. de Neeling, A.; Broek, M.V.D.; Spalburg, E.; van Santen-Verheuvel, M.; Dam-Deisz, W.; Boshuizen, H.; van de Giessen, A.; van Duijkeren, E.; Huijsdens, X. High prevalence of methicillin resistant Staphylococcus aureus in pigs. Vet. Microbiol. 2007, 122, 366-372. [CrossRef]

39. Fitzgerald, J.R. Livestock-associated Staphylococcus aureus: Origin, evolution and public health threat. Trends Microbiol. 2012, 20, 192-198. [CrossRef]

40. Kosecka-Strojek, M.; Ilczyszyn, W.M.; Buda, A.; Polakowska, K.; Murzyn, K.; Panz, T.; Bialecka, A.; Kasprowicz, A.; Jakubczak, A.; Krol, J.; et al. Multiple-locus variable-number tandem repeat fingerprinting as a method for rapid and cost-effective typing of animal-associated Staphylococcus aureus strains from lineages other than sequence type 398. J. Med Microbiol. 2016, 65, 1494-1504. [CrossRef]

41. Morcillo, A.; Castro, B.; Rodríguez-Álvarez, C.; Abreu, R.; Aguirre-Jaime, A.; Arias, A. Descriptive Analysis of Antibiotic-Resistant Patterns of Methicillin-Resistant Staphylococcus aureus (MRSA) st398 Isolated from Healthy Swine. Int. J. Environ. Res. Public Heal. 2015, 12, 611-622. [CrossRef]

42. Wulf, M.; Sørum, M.; Van Nes, A.; Skov, R.; Melchers, W.; Klaassen, C.; Voss, A. Prevalence of methicillin-resistant Staphylococcus aureus among veterinarians: An international study. Clin. Microbiol. Infect. 2008, 14, 29-34. [CrossRef]

43. European Food Safety Authority: Analysis of the baseline survey on the prevalence of methicillin-resistant Staphylococcus aureus (MRSA) in holdings with breeding pigs, in the EU, 2008, Part A: MRSA prevalence estimates; on request from the European Commission. EFSA J. 2009, 1376, 1-82.

44. Huber, H.; Giezendanner, N.; Stephan, R.; Zweifel, C. Genotypes, Antibiotic Resistance Profiles and Microarray-Based Characterization of Methicillin-Resistant Staphylococcus aureus Strains Isolated from Livestock and Veterinarians in Switzerland. Zoonoses Public Heal. 2010, 58, 343-349. [CrossRef]

45. Hanssen, A.-M.; Sollid, J.U.E. SCCmec in staphylococci: Genes on the move. FEMS Immunol. Med Microbiol. 2006, 46, 8-20. [CrossRef] [PubMed]

46. Ito, T.; Okuma, K.; Ma, X.X.; Yuzawa, H.; Hiramatsu, K. Insights on antibiotic resistance of Staphylococcus aureus from its whole genome: Genomic island SCC. Drug Resist. Updat. 2003, 6, 41-52. [CrossRef]

47. Strandén, A.M.; Frei, R.; Adler, H.; Flückiger, U.; Widmer, A.F. Emergence of SCCmec Type IV as the Most Common Type of Methicillin-Resistant Staphylococcus aureus in a University Hospital. Infect. 2008, 37, 44-48. [CrossRef] [PubMed]

48. Fossum, A.; Bukholm, G. Increased incidence of methicillin-resistant Staphylococcus aureus ST80, novel ST125 and SCCmecIV in the south-eastern part of Norway during a 12-year period. Clin. Microbiol. Infect. 2006, 12, 627-633. [CrossRef] [PubMed]

49. Chen, C.-J.; Huang, Y.-C.; Chiu, C.-H.; Su, L.-H.; Lin, T.-Y. Clinical Features and Genotyping Analysis of Community-Acquired Methicillin-Resistant Staphylococcus aureus Infections in Taiwanese Children. Pediatr. Infect. Dis. J. 2005, 24, 40-45. [CrossRef] [PubMed]

50. Nakaminami, H.; Takadama, S.; Ito, A.; Hasegawa, M.; Jono, C.; Noguchi, M.; Shoshi, M.; Wajima, T.; Fujii, T.; Maruyama, H.; et al. Characterization of SCCmec type IV methicillin-resistant Staphylococcus aureus clones increased in Japanese hospitals. J. Med Microbiol. 2018, 67, 769-774. [CrossRef]

51. Choo, E.J. Community-Associated Methicillin-Resistant Staphylococcus aureus in Nosocomial Infections. Infect. Chemother. 2017, 49, 158-159. [CrossRef] [PubMed]

52. David, M.Z.; Cadilla, A.; Boyle-Vavra, S.; Daum, R.S. Replacement of HA-MRSA by CA-MRSA Infections at an Academic Medical Center in the Midwestern United States, 2004-5 to 2008. PLoS ONE 2014, 9, e92760. [CrossRef]

53. Ho, J.; O’Donoghue, M.; Guardabassi, L.; Moodley, A.; Boost, M. Characterization of Methicillin-Resistant Staphylococcus aureus Isolates from Pig Carcasses in Hong Kong. Zoonoses Public Heal. 2012, 59, 416-423. [CrossRef]

54. Rodríguez-López, P.; Filipello, V.; Di Ciccio, P.A.; Pitozzi, A.; Ghidini, S.; Scali, F.; Ianieri, A.; Zanardi, E.; Losio, M.N.; Simon, A.C.; et al. Assessment of the Antibiotic Resistance Profile, Genetic Heterogeneity and Biofilm Production of Methicillin-Resistant Staphylococcus aureus (MRSA) Isolated from The Italian Swine Production Chain. Foods 2020, 9, 1141. [CrossRef]

55. O'Connor, A.M.; McManus, B.A.; Coleman, D.C. First description of novel arginine catabolic mobile elements (ACMEs) types IV and V harboring a kdp operon in Staphylococcus epidermidis characterized by whole genome sequencing. Infect. Genet. Evol. 2018, 61, 60-66. [CrossRef] [PubMed]

56. Diep, B.A.; Gill, S.R.; Chang, R.F.; Phan, T.H.; Chen, J.H.; Davidson, M.G.; Lin, F.; Lin, J.; Carleton, H.A.; Mongodin, E.F.; et al. Complete genome sequence of USA300, an epidemic clone of community-acquired meticillin-resistant Staphylococcus aureus. Lancet 2006, 367, 731-739. [CrossRef]

57. Shore, A.C.; Rossney, A.S.; Brennan, O.M.; Kinnevey, P.M.; Humphreys, H.; Sullivan, D.J.; Goering, R.V.; Ehricht, R.; Monecke, S.; Coleman, D.C. Characterization of a Novel Arginine Catabolic Mobile Element (ACME) and Staphylococcal Chromosomal Cassette mec Composite Island with Significant Homology to Staphylococcus epidermidis ACME Type II in Methicillin-Resistant Staphylococcus aureus Genotype ST22-MRSA-IV. Antimicrob. Agents Chemother. 2011, 55, 1896-1905. [CrossRef] 
58. Sabat, A.J.; Ilczyszyn, W.M.; Van Rijen, M.; Akkerboom, V.; Sinha, B.; Kluytmans, J.; Miedzobrodzki, J.; Grundmann, H.; Friedrich, A.W. Genome-wide analysis reveals two novel mosaic regions containing an ACME with an identical DNA sequence in the MRSA ST398-t011 and MSSA ST8-t008 isolates. J. Antimicrob. Chemother. 2015, 70, 1298-1302. [CrossRef]

59. Pi, B.; Yu, M.; Chen, Y.; Yu, Y.; Li, L. Distribution of the ACME-arcA gene among meticillin-resistant Staphylococcus haemolyticus and identification of a novel ccr allotype in ACME-arcA-positive isolates. J. Med Microbiol. 2009, 58, 731-736. [CrossRef]

60. McManus, B.A.; O'Connor, A.M.; Egan, S.A.; Flanagan, P.R.; Coleman, D.C. First description of arginine catabolic mobile element (ACME) type VI harboring the $k d p$ operon only in Staphylococcus epidermidis using short and long read whole genome sequencing: Further evidence of ACME diversity. Infect. Genet. Evol. 2019, 71, 51-53. [CrossRef]

61. McCarthy, H.; Rudkin, J.K.; Black, N.S.; Egallagher, L.; Eo'Neill, E.; O'Gara, J.P. Methicillin resistance and the biofilm phenotype in Staphylococcus aureus. Front. Cell. Infect. Microbiol. 2015, 5, 1. [CrossRef] [PubMed]

62. Juda, M.; Helon, P.; Malm, A. Anti-adhesive and anti-biofilm activities in vitro of linezolid, vancomycin, tigecycline and daptomycin against Staphylococcus haemolyticus. Acta Pol. Pharm. 2016, 73, 1539-1543. [PubMed]

63. Fernández-Barat, L.; Motos, A.; Panigada, M.; Álvarez-Lerma, F.; Viña, L.; Lopez-Aladid, R.; Ceccato, A.; Bassi, G.L.; Nicolau, D.P.; Lopez, Y.; et al. Comparative efficacy of linezolid and vancomycin for endotracheal tube MRSA biofilms from ICU patients. Crit. Care 2019, 23, 251. [CrossRef]

64. Kosecka-Strojek, M.; Buda, A.; Międzobrodzki, J. Staphylococcal Ecology and Epidemiology. In Pet-To-Man Travelling Staphylococci, 1st ed.; Savini, V., Ed.; Elsevier Academic Press: Cambridge, MA, USA, 2018; pp. 11-24.

65. Takeuchi, F.; Watanabe, S.; Baba, T.; Yuzawa, H.; Ito, T.; Morimoto, Y.; Kuroda, M.; Cui, L.; Takahashi, M.; Ankai, A.; et al. Whole-Genome Sequencing of Staphylococcus haemolyticus Uncovers the Extreme Plasticity of Its Genome and the Evolution of Human-Colonizing Staphylococcal Species. J. Bacteriol. 2005, 187, 7292-7308. [CrossRef]

66. Biavasco, F.; Vignaroli, C.; Varaldo, P.E. Glycopeptide Resistance in Coagulase-Negative Staphylococci. Eur. J. Clin. Microbiol. Infect. Dis. 2000, 19, 403-417. [CrossRef] [PubMed]

67. Miragaia, M. Factors Contributing to the Evolution of mecA-Mediated $\beta$-lactam Resistance in Staphylococci: Update and New Insights From Whole Genome Sequencing (WGS). Front. Microbiol. 2018, 9, 2723. [CrossRef]

68. de Gopegui, E.R.; Juan, C.; Zamorano, L.; Pérez, J.L.; Oliver, A. Transferable Multidrug Resistance Plasmid Carrying $c f r$ Associated with tet $(L)$, ant $\left(4^{\prime}\right)$-Ia, and dfrK Genes from a Clinical Methicillin-Resistant Staphylococcus aureus ST125 Strain. Antimicrob. Agents Chemother. 2012, 56, 2139-2142. [CrossRef]

69. Kehrenberg, C.; Cuny, C.; Strommenger, B.; Schwarz, S.; Witte, W. Methicillin-Resistant and -Susceptible Staphylococcus aureus Strains of Clonal Lineages ST398 and ST9 from Swine Carry the Multidrug Resistance Gene cfr. Antimicrob. Agents Chemother. 2008, 53, 779-781. [CrossRef]

70. Kehrenberg, C.; Schwarz, S. Distribution of Florfenicol Resistance Genes fexA and cfr among Chloramphenicol-Resistant Staphylococcus Isolates. Antimicrob. Agents Chemother. 2006, 50, 1156-1163. [CrossRef] [PubMed]

71. Woo, P.C.Y.; Leung, A.S.P.; Leung, K.W.; Yuen, K.Y. Identification of slide coagulase positive, tube coagulase negative Staphylococcus aureus by 16 S ribosomal RNA gene sequencing. Mol. Pathol. 2001, 54, 244-247. [CrossRef]

72. Poyart, C.; Quesne, G.; Boumaila, C.; Trieu-Cuot, P. Rapid and Accurate Species-Level Identification of Coagulase-Negative Staphylococci by Using the $\operatorname{sodA}$ Gene as a Target. J. Clin. Microbiol. 2001, 39, 4296-4301. [CrossRef] [PubMed]

73. Martineau, F.; Picard, F.J.; Ke, D.; Paradis, S.; Roy, P.H.; Ouellette, M.; Bergeron, M.G. Development of a PCR Assay for Identification of Staphylococci at Genus and Species Levels. J. Clin. Microbiol. 2001, 39, 2541-2547. [CrossRef] [PubMed]

74. Mellmann, A.; Becker, K.; Von Eiff, C.; Keckevoet, U.; Schumann, P.; Harmsen, D. Sequencing and Staphylococci Identification. Emerg. Infect. Dis. 2006, 12, 333-336. [CrossRef] [PubMed]

75. Kahl, B.C.; Mellmann, A.; Deiwick, S.; Peters, G.; Harmsen, D. Variation of the Polymorphic Region X of the Protein A Gene during Persistent Airway Infection of Cystic Fibrosis Patients Reflects Two Independent Mechanisms of Genetic Change in Staphylococcus aureus. J. Clin. Microbiol. 2005, 43, 502-505. [CrossRef] [PubMed]

76. Enright, M.C.; Day, N.P.J.; Davies, C.E.; Peacock, S.J.; Spratt, B.G. Multilocus Sequence Typing for Characterization of MethicillinResistant and Methicillin-Susceptible Clones of Staphylococcus aureus. J. Clin. Microbiol. 2000, 38, 1008-1015. [CrossRef]

77. Cavanagh, J.P.; Klingenberg, C.; Hanssen, A.-M.; Fredheim, E.A.; Francois, P.; Schrenzel, J.; Flægstad, T.; Sollid, J.E. Core genome conservation of Staphylococcus haemolyticus limits sequence based population structure analysis. J. Microbiol. Methods 2012, 89, 159-166. [CrossRef] [PubMed]

78. Jolley, K.A.; Bray, J.E.; Maiden, M.C.J. Open-access bacterial population genomics: BIGSdb software, the PubMLST.org website and their applications. Wellcome Open Res. 2018, 3, 124. [CrossRef] [PubMed]

79. Milheiriço, C.; Oliveira, D.C.; De Lencastre, H. Update to the Multiplex PCR Strategy for Assignment of mec Element Types in Staphylococcus aureus. Antimicrob. Agents Chemother. 2007, 51, 3374-3377. [CrossRef]

80. Kondo, Y.; Ito, T.; Ma, X.X.; Watanabe, S.; Kreiswirth, B.N.; Etienne, J.; Hiramatsu, K. Combination of Multiplex PCRs for Staphylococcal Cassette Chromosome mec Type Assignment: Rapid Identification System for mec, ccr, and Major Differences in Junkyard Regions. Antimicrob. Agents Chemother. 2006, 51, 264-274. [CrossRef]

81. Diep, B.A.; Stone, G.G.; Basuino, L.; Graber, C.J.; Miller, A.; Etages, S.D.; Jones, A.; Palazzolo-Ballance, A.M.; Perdreau-Remington, F.; Sensabaugh, G.F.; et al. The Arginine Catabolic Mobile Element and Staphylococcal Chromosomal Cassette mec Linkage: Convergence of Virulence and Resistance in the USA300 Clone of Methicillin-Resistant Staphylococcus aureus. J. Infect. Dis. 2008, 197, 1523-1530. [CrossRef] 
82. O'Connor, A.M.; McManus, B.A.; Kinnevey, P.M.; Brennan, G.I.; Fleming, T.E.; Cashin, P.J.; O'Sullivan, M.; Polyzois, I.; Coleman, D.C. Significant Enrichment and Diversity of the Staphylococcal Arginine Catabolic Mobile Element ACME in Staphylococcus epidermidis Isolates From Subgingival Peri-implantitis Sites and Periodontal Pockets. Front. Microbiol. 2018, 9, 1558. [CrossRef]

83. Costa, S.S.; Sobkowiak, B.; Parreira, R.; Edgeworth, J.D.; Viveiros, M.; Clark, T.G.; Couto, I. Genetic Diversity of norA, Coding for a Main Efflux Pump of Staphylococcus aureus. Front. Genet. 2019, 9, 710. [CrossRef]

84. Marco, L.; Liliana, G.; Anna, B.; Annarita, M. Intrinsic role of coagulase negative staphylococci norA-like efflux system in fluoroquinolones resistance. AIMS Microbiol. 2017, 3, 908-914. [CrossRef]

85. Vakulenko, S.B.; Donabedian, S.M.; Voskresenskiy, A.M.; Zervos, M.J.; Lerner, S.A.; Chow, J.W. Multiplex PCR for Detection of Aminoglycoside Resistance Genes in Enterococci. Antimicrob. Agents Chemother. 2003, 47, 1423-1426. [CrossRef]

86. Pyzik, E.; Marek, A.; Stępień-Pyśniak, D.; Urban-Chmiel, R.; Jarosz, Ł.S.; Jagiełło-Podębska, I. Detection of antibiotic resistance and classical enterotoxin genes in coagulase -negative staphylococci isolated from poultry in Poland. J. Veter- Res. 2019, 63, 183-190. [CrossRef]

87. Brenciani, A.; Fioriti, S.; Morroni, G.; Cucco, L.; Morelli, A.; Pezzotti, G.; Paniccià, M.; Antonelli, A.; Magistrali, C.F.; Rossolini, G.M.; et al. Detection in Italy of a porcine Enterococcus faecium isolate carrying the novel phenicol-oxazolidinonetetracycline resistance gene poxtA. J. Antimicrob. Chemother. 2018, 74, 817-818. [CrossRef]

88. Tristan, A.; Ying, L.; Bes, M.; Etienne, J.; Vandenesch, F.; Lina, G. Use of Multiplex PCR To Identify Staphylococcus aureus Adhesins Involved in Human Hematogenous Infections. J. Clin. Microbiol. 2003, 41, 4465-4467. [CrossRef]

89. Jarraud, S.; Mougel, C.; Thioulouse, J.; Lina, G.; Meugnier, H.; Forey, F.; Nesme, X.; Etienne, J.; Vandenesch, F. Relationships between Staphylococcus aureus Genetic Background, Virulence Factors, agr Groups (Alleles), and Human Disease. Infect. Immun. 2002, 70, 631-641. [CrossRef] [PubMed]

90. El-Baz, R.; Rizk, D.E.; Barwa, R.; Hassan, R. Virulence characteristics and molecular relatedness of methicillin resistant Staphylococcus aureus harboring different staphylococcal cassette chromosome mec. Microb. Pathog. 2017, 113, 385-395. [CrossRef] [PubMed]

91. Pinheiro-Hubinger, L.; Brito, C.I.; De Oliveira, A.; Martins, P.Y.F.; Pereira, V.C.; Cunha, M.D.L.R.D.S.D. Staphylococcus epidermidis and Staphylococcus haemolyticus: Molecular Detection of Cytotoxin and Enterotoxin Genes. Toxins 2015, 7, 3688-3699. [CrossRef] [PubMed]

92. Rohde, H.; Knobloch, J.K.M.; Horstkotte, M.A.; Mack, D.; Arciola, C.R.; Montanaro, L.; Baldassarri, L. Correlation of Staphylococcus aureus icaADBC Genotype and Biofilm Expression Phenotype. J. Clin. Microbiol. 2001, 39, 4595-4596. [CrossRef]

93. Kiem, S.; Oh, W.S.; Peck, K.R.; Lee, N.Y.; Lee, J.-Y.; Song, J.-H.; Hwang, E.S.; Kim, E.-C.; Cha, C.Y.; Choe, K.-W. Phase Variation of Biofilm Formation in Staphylococcus aureus by IS256Insertion and Its Impact on the Capacity Adhering to Polyurethane Surface. J. Korean Med Sci. 2004, 19, 779-782. [CrossRef]

94. Miller, K.; Dunsmore, C.J.; Fishwick, C.W.G.; Chopra, I. Linezolid and Tiamulin Cross-Resistance in Staphylococcus aureus Mediated by Point Mutations in the Peptidyl Transferase Center. Antimicrob. Agents Chemother. 2008, 52, 1737-1742. [CrossRef] [PubMed]

95. Mendes, R.E.; Deshpande, L.M.; Farrell, D.J.; Spanu, T.; Fadda, G.; Jones, R.N. Assessment of linezolid resistance mechanisms among Staphylococcus epidermidis causing bacteraemia in Rome, Italy. J. Antimicrob. Chemother. 2010, 65, 2329-2335. [CrossRef] [PubMed] 